\title{
Pengukuran tingkat kebisingan pada kapal pukat cincin KM. Sumber Jaya bermesin tempel di perairan Teluk Manado
}

\author{
Noise level measurement on outboard engine purse seiner KM Sumber Jaya in Manado Bay
}

\author{
OTNIEL T. USIOR*, FRANSISCO P.T. PANGALILA dan FRANGKY E. KAPARANG \\ Program Studi pemanfaatan Sumberdaya Perikanan, Fakultas Perikanan dan Ilmu Kelautan, \\ Universitas Sam Ratulangi, Manado 95115
}

\begin{abstract}
An outboard engine purse seiner has a main engine and an auxiliary engine to pull the net. These engines produce noise due to their vibration and loud sound when operated. The noise level affects the comfort and hearing health of crew and fishermen during their work and rest time. Therefore a measurement of noise levels on a fishing boat had been done to compare them to the allowable noise level of $80 \mathrm{~dB}$ by Ministry of Health. This research is descriptive and experimental. Noise levels were measured at the following conditions: cruising to the fishing ground, setting, hauling, and returning to base. Measurements were done using a decibel meter at points of $1 \mathrm{~m}$ apart on the ship and $1 \mathrm{~m}$ above the ship deck. Noise data were analyzed and plotted using Surfer 10 software. The experiment was conducted in a small purse seine fishing vessels KM. Sumber Jaya based at Tumumpa Coastal Fishery Port, Manado, North Sulawesi. This research was carried out for three months, from August to October, 2014. The highest noise level at cruising to the fishing ground was $97.8 \mathrm{~dB}$ and the lowest value was $48.7 \mathrm{~dB}$. The highest noise levels during setting was $89.9 \mathrm{~dB}$ and the lowest was $30.0 \mathrm{~dB}$. The highest noise level during hauling was $77.64 \mathrm{~dB}$ and the lowest was $31.7 \mathrm{~dB}$. The highest noise level at the time of return to fishing base was $99.7 \mathrm{~dB}$, and the lowest was $51.7 \mathrm{~dB}$.
\end{abstract}

Keywords: noise threshold, small purse seiner

\begin{abstract}
ABSTRAK
Kapal purse seine bermesin tempel memiliki mesin penggerak utama maupun alat bantu menarik jaring. Hal ini menyebabkan timbulnya kebisingan yang disebabkan oleh getaran pada mesin kapal tersebut sewaktu dioperasikan. Tingkat kebisingan ini dapat mempengaruhi tingkat kenyamanan dan kesehatan pendengaran ABK dan nelayan sewaktu bekerja maupun jam istirahat. Untuk itu dilakukan pengukuran tingkat kebisingan di kapal ikan yang nantinya akan bandingkan dengan tingkat kebisingan yang diizinkan Departemen Kesehatan sebesar 80 dB. Penelitian ini bersifat deskriptif dan experiment. Pengumpulan data tingkat kebisingan ini dilakukan pada kondisi sebagai berikut: perjalanan ke fishing ground, melepaskan alat (setting), menarik alat (hauling), dan kembali ke pangkalan. Pengambilan data kebisingan diukur pada tiap-tiap titik $1 \mathrm{~m}$ yang berbeda di kapal dan tinggi sound desibel meter adalah $1 \mathrm{~m}$ dari geladak kapal. Data dianalisis dengan mengambarkan pola penyebaran kebisingan dengan mengunakan Software Surver 10. Penelitian dilaksanakan di kapal ikan pukat cincin kecil KM. Sumber Jaya yang berpangkalan di Pelabuhan Perikanan Pantai Tumumpa, Kota Manado, Provinsi Sulawesi Utara. Penelitian ini dilaksanakan selama tiga bulan, dari bulan Agustus sampai bulan Oktober 2014. Tingkat kebisingan yang tertinggi pada saat menuju ke fishing ground berada sebesar 97,8 dB dan nilai terendah sebesar 48,7 dB. Tingkat kebisingan yang tertingggi pada saat alat tangkap dilepas sebesar 89,9 dB dan terendah sebesar 30,0 dB. Tingkat kebisingan yang tertinggi pada kondisi alat tangkap ditarik sebesar 77,64 dB dan terendah sebesar 31,7 dB. Tingkat kebisingan yang tertinggi pada saat kembali ke fishing base sebesar 99,7 dB, dan terendah sebesar 51,7 dB.
\end{abstract}

Kata-kata kunci: tingkat kebisingan, kapal purse seine

\footnotetext{
*Penulis untuk penyuratan; email: otis.tigen@gmail.com
} 


\section{PENDAHULUAN}

Pada dasarnya kapal laut memiliki berbagai macam jenis yang disesuaikan dengan tujuan penggunaannya. Namun pada umumnya kapal laut merupakan sarana dalam mengangkut atau memindahkan sesuatu dari daerah yang satu ke daerah yang lain melalui air. Hal ini menyebabkan timbulnya kebisingan yang disebabkan oleh getaran pada mesin penggerak utama kapal (Dinas Perikanan dan Kelautan, 2001). Kapal adalah kendaraan air dengan bentuk dan jenis apapun, yang digerakkan dengan tenaga mekanik, tenaga angin, atau ditunda termasuk kendaraan yang berdaya dukung dinamis, kendaraaan di bawah permukaan air, serta alat apung dan bangunan terapung yang tidak berpindah-pindah (Undangundang Republik Indonesia No 21 Tahun 1992 tentang Pelayaran).

Berbagai mesin dan peralatan kapal ikan yang menimbulkan kebisingan sewaktu dioperasikan. Kebisingan ini mempengaruhi tingkat kenyamanan ABK dan nelayan sewaktu bekerja maupun jam istirahat yang tentunya mempengaruhi kesehatan nelayan dan ABK pada alat pendengaran maupun kesehatan seluruh tubuhnya. Untuk itu dilakukan pengukuran tingkat kebisingan di kapal ikan yang nantinya akan bandingkan dengan tingkat kebisingan yang diizinkan Departemen Kesehatan adalah $80 \mathrm{~dB}$.

Menurut Tambunan (2005) jenis dan jumlah sumber suara (kebisingan) di tempat kerja sangat beragam di antaranya adalah suara mesin, benturan antara alat kerja dan benda kerja, aliran, material (aliran gas, air atau material-material cair dalam pipa), dan manusia.

Untuk dapat mengendalikan bunyi bising yang terjadi di kapal, terlebih dahulu perlu dipelajari bagaimana cara penyebaran bunyi bising tersebut. Adapun penyebaran dan perambatan bunyi bising berbagai ruang di kapal dapat melalui dua jalur, yaitu: melalui udara dan menjadi bunyi bising berawal dari udara sehingga dinamakan air borne noise, dan melalui bagian-bagian konstruksi lambung kapal yang kemudian bunyi bising terjadi disebut sebagai structure borne noise.

Air borne noise yang disebarkan oleh suatu sumber kebisingan setelah sampai di suatu ruang yang berdinding dapat menjadi penyebab timbulnya getaran dan dapat menimbulkan bunyi bising yang berasal dari dinding yang bergetar tersebut. Dengan demikian air borne noise tersebut dapat berubah menjadi structure borne noise. Sebaliknya structure borne noise yang berasal dari suatu sumber kebisingan setelah merambat dan sampai di suatu dinding pada ruangan lain dapat mengantarkan udara di ruangan tersebut dan dapat menimbulkan bunyi bising sehinga berubah menjadi air borne noise (Sastrodiwongso, 1985).

Keputusan Menteri Tenaga Kerja Nomor: KEP51/MEN/1999 tentang nilai ambang batas faktor fisika di tempat kerja menyatakan bahwa nilai ambang batas kebisingan adalah angka $80 \mathrm{~dB}$ yang dianggap aman untuk sebagian besar tenaga kerja bila bekerja 8 jam per hari atau 40 jam per minggu.

Tujuan penelitian adalah untuk mengetahui nilai tingkat kebisingan tertinggi pada kapal ikan (pukat cincin) bermesin tempel di Pelabuhan Perikanan Pantai Tumumpa, Kota Manado, Provinsi Sulawesi Utara; dan untuk membandingkan hasil perhitungan tingkat kebisingan mesin bermotor tempel dengan nilai ambang batas (NAB) kebisingan yang diizinkan.

Penelitian dilaksanakan di kapal ikan pukat cincin kecil KM. Sumber Jaya yang berpangkalan di Pelabuhan Perikanan Pantai Tumumpa, Kota Manado, Provinsi Sulawesi Utara. Pelaksanaan Penelitian ini dilaksanakan selama tiga bulan, dari bulan Agustus sampai bulan Oktober 2014.

\section{METODE PENELITIAN}

Penelitian ini bersifat deskriptif dan eksperimen yaitu, metode dalam meneliti suatu objek untuk mendapatkan persamaan-persamaan dan perbedaan-perbedaan tentang benda-benda terhadap suatu idea atau juga membandingkan kesamaan pandangan dan perubahan tentang kasus yang sedang diselidiki terhadap peristiwa pada masa sekarang dengan tujuan menggambarkan keadaan dari kasus yang sedang diselidiki (Arikuno, 1987).

Pengumpulan data tingkat kebisingan ini dilakukan pada kondisi sebagai berikut: perjalanan ke fishing ground, melepaskan alat (setting), menariki alat (hauling), kembali ke pangkalan. Pengkuran RPM dilakukan dengan mengukur putaran roda gila dari mesin yang telah dihidupkan.

Pengambilan data kebisingan diukur pada tiaptiap titik $1 \mathrm{~m}$ yang berbeda di kapal dan tinggi sound desibel meter adalah $1 \mathrm{~m}$ dari kapal, sebagai mana digambarkan pada Gbr. 1. 


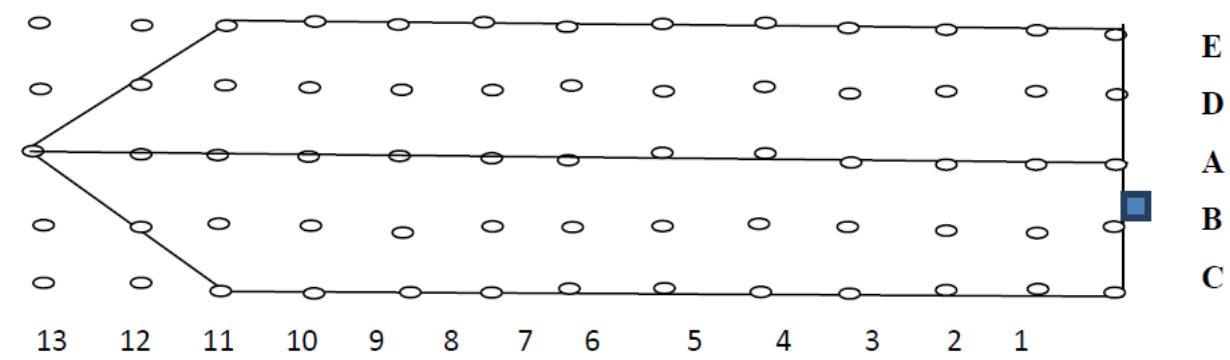

Gambar 1. Titik pengukuran kebisingan pada kapal purse seine

Data dianalisis dengan mengambarkan pola penyebaran kebisingan dengan mengunakan perangkat lunak Surfer 10. Gambaran kondisi kebisingan akan dibandingkan dalam beberapa kondisi yang diukur. Dari pola penyebaran kebisingan tersebut akan terlihat daerah mana yang melebihi nilai ambang batas kebisingan.

\section{HASIL DAN PEMBAHASAN}

\section{Kapal pukat cincin}

Kapal pukat cincin yang diteliti adalah KM. Sumber Jaya dengan panjang $13 \mathrm{~m}$ dan lebar $2 \mathrm{~m}$ serta dalam 1,53 m. Kapal ini dibuat 20 tahun yang lalu, kapal pukat cincin ini dikelompokkan sebagai kapal pukat cincin unyil atau kecil. Jaring yang dipakai di kapal pukat cincin ini panjangnya 160 depa $(240 \mathrm{~m})$ dan lebar 17 depa $(25,5 \mathrm{~m})$. Pukat cincin ini menggunakan alat bantu penarik tali cincin yang dinamakan winch. Daya mesin tempel yang digunakan oleh nelayan adalah bermerek Suzuki 40 Hp dengan masa pakai sekitar 6 tahun. Kapal pukat cincin yang dipakai dalam pengukuran tingkat kebisingan ini tidak memiliki rumah.

Pengoperasian soma pajeko ini diawali dangan kegiatan menuju ke fishing grond selama perjalanan kurang lebih 15 menit. Setelah sampai di tempat operasi nelayan (tonaas) mengamati permukaan air sambil mencari gerombolan ikan. Setelah menemukan gerombolan ikan, maka perahu dan alat segera disiapkan untuk melepas alat. Jaring ditebarkan memutar ke arah kiri. Yang lebih dahulu dilepaskan adalah pelampung awal, selanjutnya secara bertahap bagian jaring akan tertebar dengan sendiri karena arah gerak kapal yang melingkar. Setelah kedua ujung tali pelampung dan tali cincin bertemu maka segera ditarik tali pelampung dan tali cincin. Untuk mempercepat penarikan tali cincin maka dihidupkan winch untuk menarik tali cincin tersebut. Secara perlahan-lahan dinding jaring dinaikkan ke atas kapal sampai pada bagian kantong. Hasil tangkapan yang terkumpul di bagian kantong diangkat dengan sero ke dalam drum yang disiapkan. Kemudian seluruh bagian kantong diangkat ke atas perahu dan kapal kembali ke fishing base.

\section{Nilai pengukuran kebisingan saat menuju fishing ground (dB)}

Nilai pengukuran kebisingan saat menuju fishing ground seperti pada Tabel 2. Nilai kebisingan yang tertingggi pada saat menuju ke fishing ground berada di ordinat A1 sebesar $97,8 \mathrm{~dB}$ di daerah mesin dan nilai terendah berada di ordinat E13 sebesar 48,7 dB yaitu di daerah haluan. Pada daerah $2 \mathrm{~m}$ dari buritan terlihat berada di atas 85 $\mathrm{dB}$.

Hal ini disebabkan karena letak mesin pada posisi buritan sebelah kiri yang menimbulkan bunyi di atas nilai ambang kebisingan. RPM mesin saat menuju ke fishing ground adalah $1653 \mathrm{rpm}$. Sedangkan $50 \mathrm{~dB}$ sampai $70 \mathrm{~dB}$ adalah daerah yang aman bagi nelayan yang letaknya dari bagian tengah perahu, ke arah haluan

Menurut Sumantri (2014), nilai kebisingan yang tertinggi KM Omega jaya pada kondisi mesin utama menyala berada di C13 sebesar 105,36 dB (A). Nilai terendah berada di C0 sebesar 72,63 dB (A). Nilai perbedaan antara nilai kebisingan tertinggi dan terendah sebesar 32,91 dB (A) dengan jarak $13 \mathrm{~m}$ dan rata-rata pengurangan nilai kebisingan sebesar 2,3 dB (A) di setiap penambahan jarak $1 \mathrm{~m}$. Nilai rata-rata kebisingan secara keseluruhan sebesar 91,19 dB (A). 
Tabel 2. Nilai pengukuran kebisingan saat nelayan menuju fishing ground (dB)

\begin{tabular}{cccccc}
\hline NO & C (1) & B (2) & A (3) & D (4) & E (5) \\
\hline 1 & 91.0 & 93.3 & $97.8 * *$ & 92.0 & 90.2 \\
2 & 82.2 & 89.4 & 91.6 & 88.7 & 85.4 \\
3 & 76.1 & 77.8 & 80.0 & 77.4 & 75.2 \\
4 & 75.0 & 74.9 & 76.6 & 77.1 & 72.6 \\
5 & 74.1 & 71.9 & 76.4 & 75.4 & 70.4 \\
6 & 72.1 & 70.7 & 79.0 & 71.7 & 68.7 \\
7 & 70.2 & 64.2 & 72.2 & 69.5 & 66.5 \\
8 & 69.0 & 60.5 & 70.3 & 68.2 & 64.4 \\
9 & 54.6 & 58.9 & 69.5 & 65.4 & 60.2 \\
10 & 50.4 & 56.4 & 67.8 & 63.3 & 58.5 \\
11 & 49.2 & 53.2 & 65.6 & 62.7 & 54.3 \\
12 & 46.1 & 50.6 & 63.8 & 60.5 & 51.6 \\
13 & 42.9 & 49.8 & 60.5 & 50.1 & $48.7 *$ \\
\hline
\end{tabular}

** nilai kebisingan tertinggi, * nilai kebisingan terendah

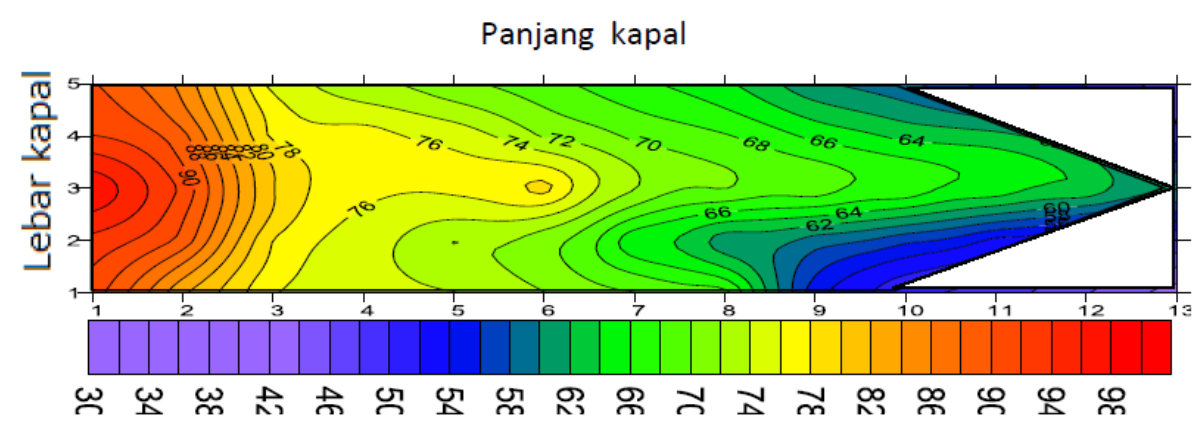

Gambar 2. Pengukuran kebisingan pada saat nelayan menuju fishing ground

\section{Nilai pengukuran kebisingan saat alat di lepas}

Nilai pengukuran kebisingan saat alat dilepas seperti pada Tabel 3. Terlihat bahwa nilai kebisingan yang tertingggi pada saat alat dilepas berada di ordinat A5 sebesar $89,9 \mathrm{~dB}$. dan nilai terendah berada di ordinat E13 sebesar 30,0 dB.

Pada Gbr. 3 ditunjukkan bahw nilai kebisingan yang paling tinggi berada di tengah kapal dan samping kiri kapal yaitu, A(3) 5, B (2) 6 dan C (1) $5 \mathrm{~dB}$. Pada waktu alat dilepas, timah dan pelampung yang tergesek di dek kapal dan samping kiri kapal sehingga mengakibatkan keributan.

\section{Nilai pengukuran kebisingan saat alat di tarik}

Nilai pengukuran kebisingan saat alat dilepas seperti pada Tabel 4. 
Tabel 3. Nilai pengukuran kebisingan saat alat di lepas $(\mathrm{dB})$

\begin{tabular}{cccccc}
\hline NO & C (1) & B (2) & A (3) & D (4) & E (5) \\
\hline 1 & 60.8 & 64.8 & 76.9 & 59.8 & 46.2 \\
2 & 58.7 & 62.4 & 74.6 & 56.6 & 44.6 \\
3 & 56.4 & 60.7 & 72.0 & 54.2 & 42.7 \\
4 & 52.2 & 59.3 & 69.6 & 50.1 & 40.0 \\
5 & 90.6 & 78.6 & $89.9 * *$ & 66.4 & 57.3 \\
6 & 87.3 & 76.4 & 86.5 & 64.3 & 54.6 \\
7 & 84.6 & 70.1 & 82.7 & 62.1 & 52.2 \\
8 & 80.4 & 60.2 & 75.3 & 60.2 & 50.8 \\
9 & 76.7 & 59.3 & 70.1 & 58.4 & 41.9 \\
10 & 70.6 & 56.6 & 68.0 & 54.2 & 39.7 \\
11 & 64.3 & 54.2 & 64.2 & 51.4 & 36.6 \\
12 & 50.7 & 52.1 & 62.7 & 50.7 & 32.7 \\
13 & 49.0 & 50.2 & 60.1 & 47.6 & $30.0 *$ \\
\hline
\end{tabular}

** Nilai kebisingan tertinggi, *Nilai kebisingan terendah

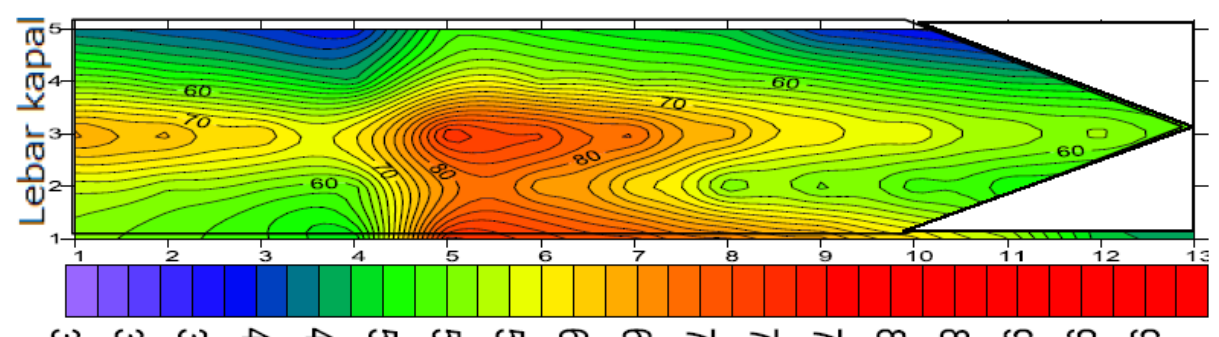

山్ల

Gambar 3. Pengukuran kebisinga pada saat alat ditarik

Tabel 4. Nilai pengukuran kebisingan pada saat alat di tarik (dB)

\begin{tabular}{cccccc}
\hline NO & C (1) & B (2) & A (3) & D (4) & E (5) \\
\hline 1 & 68.4 & 74.6 & 70.8 & 60.8 & 58.6 \\
2 & 65.6 & 72.5 & 67.5 & 59.7 & 56.7 \\
3 & 63.9 & 70.3 & 65.6 & 56.2 & 52.8 \\
4 & 60.1 & 68.8 & 62.4 & 52.1 & 50.9 \\
5 & 57.6 & 64.2 & 60.2 & 50.8 & 49.9 \\
6 & 54.3 & 75.6 & $77.4 * *$ & 60.8 & 48.2 \\
7 & 72.9 & 72.3 & 74.6 & 62.9 & 44.6 \\
8 & 70.7 & 71.8 & 70.1 & 66.7 & 42.8 \\
9 & 69.3 & 70.6 & 64.3 & 68.7 & 40.9 \\
10 & 66.9 & 68.9 & 62.4 & 61.8 & 38.7 \\
11 & 64.1 & 66.3 & 60.8 & 59.1 & 36.5 \\
12 & 58.5 & 62.5 & 57.2 & 54.3 & 33.6 \\
13 & 54.2 & 61.7 & 52.7 & 52.0 & $31.7 *$ \\
\hline
\end{tabular}

** nilai kebisingan tertinggi, *nilai kebisingan terendah 


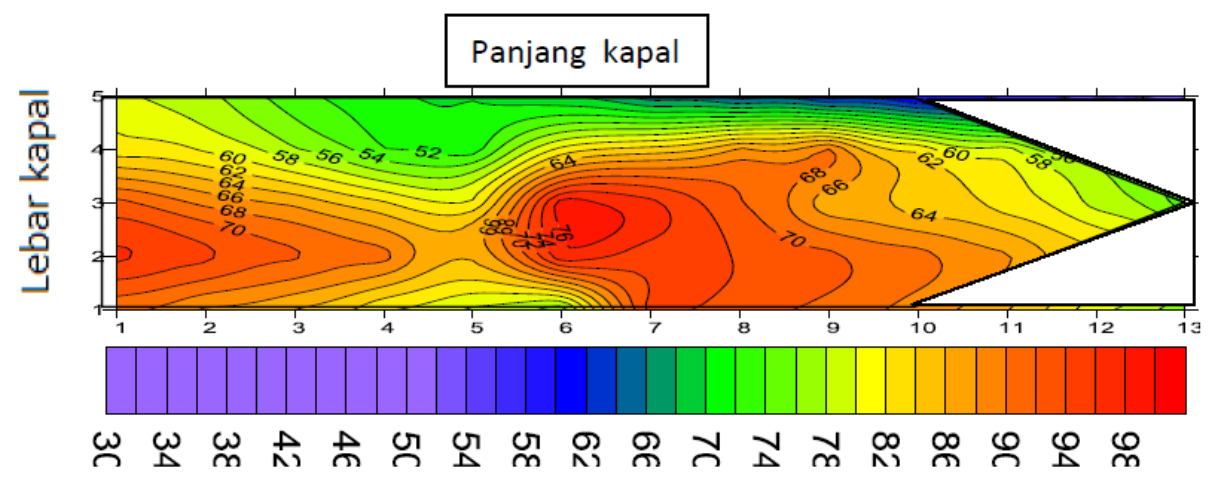

Gambar 4. Pengukuran kebisingan pada saat alat ditarik

Pada Tabel 4 dapat dilihat bahwa nilai kebisingan yang tertingggi pada kondisi alat ditarik berada di ordinat A6 sebesar 77,64 dB. dan nilai terendah, berada di ordinat E13 sebesar 31,7 dB.

Gambar 4 menunjukkan bahwa nilai kebisingan yang tertinggi berada di posisi tengah dan samping kiri kapal yaitu, saat alat ditarik dan juga ditambahkan dengan mesin pembantu penarik tali cincin (winch), Sehingga mengakibatkan tingkat kebisingan yang paling tertinggi di tengah kapal dan samping kiri kapal.

Berdasarkan Tabel 5, nilai kebisingan yang tertinggi pada kondisi mesin dihidupkan berada di A1 sebesar 99,7 dB, dan nilai terendah berada di E13 sebesar 51,7 dB. Pada Gbr. 5 ditunjukkan bahwa tingkat kebisingan yang paling tinggi berada di bagian buritan kapal yaitu: A(3) 3, B(2) 2, $\mathrm{C}(1) 3, \mathrm{D}(4) 4, \mathrm{E}(5) 5$, pada saat mesin dihidupkan dan kembali ke pelabuhan.

Tabel 5. Nilai pengukuranan kebisinnga saat kembali kefishing base $(\mathrm{dB})$

\begin{tabular}{cccccc}
\hline NO & C (1) & B (2) & A (3) & D (4) & E (5) \\
\hline 1 & 92.6 & 95.5 & $99.7 * *$ & 89.8 & 84.9 \\
2 & 90.3 & 92.8 & 97.6 & 87.9 & 82.7 \\
3 & 86.4 & 88.7 & 94.3 & 84.5 & 80.3 \\
4 & 84.8 & 84.3 & 92.5 & 79.6 & 75.6 \\
5 & 82.9 & 80.7 & 88.9 & 74.5 & 74.9 \\
6 & 80.7 & 79.5 & 84.7 & 72.4 & 70.8 \\
7 & 77.5 & 76.6 & 82.3 & 71.3 & 69.7 \\
8 & 73.8 & 72.9 & 80.4 & 70.9 & 67.5 \\
9 & 70.4 & 70.1 & 76.1 & 67.7 & 64.6 \\
10 & 68.1 & 68.0 & 75.8 & 64.5 & 62.1 \\
11 & 64.9 & 64.3 & 73.7 & 63.9 & 60.9 \\
12 & 62.5 & 62.7 & 70.9 & 59.1 & 57.8 \\
13 & 61.8 & 60.9 & 69.6 & 54.8 & $51.7 *$ \\
\hline
\end{tabular}

** Nilai kebisingan tertinggi, * kebisingan terendah 


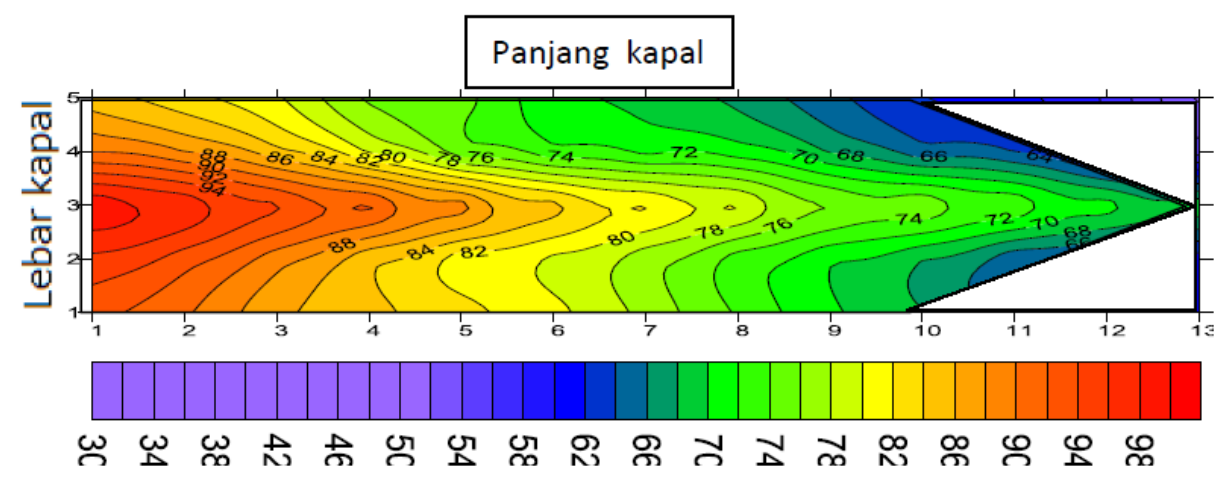

Gambar 5. Pengukuran kebisingan pada saat kembali ke pelabuhan

\section{KESIMPULAN}

Kesimpulan yang diperoleh dari penelitian ini adalah:

1. Tingkat kebisingan tertinggi saat menuju ke fishing ground adalah $97,8 \mathrm{~dB}$, saat alat dilepas sebesar 89,9 dB, saat menarik alat sebesar 77,4 $\mathrm{dB}$, dan saat kembali ke fishing base sebesar 99,7 dB.

2. Pada saat berlayar ke fishing ground maka tingkat kebisingan tertinggi (melebihi $80 \mathrm{~dB}$ ) pada bagian buritan, sedangkan pada saat melepas alat pada bagian tengah samping kiri, pada saat menarik alat juga di bagian tengah dan pada saat kembali ke pangkalan kebisingan tertinggi pada buritan kapal.

\section{DAFTAR PUSTAKA}

Arikunto, S. 1987. Prosedur Penelitian. PT. Bina Aksara, Jakarta.
Anthonie, R. 1975. Diktat seri pelayaran. Ilmu Pendidikan Mualim Pelayaran Indonesia Popeler Pertemuan Sidomulyo IV/24, Surabaya.

Dahuri, R. J., dkk. 1999. Studi sistem pemanfaatan sumberdaya perikanan laut. Laporan Pendahuluan Pusat Kegiatan sumberdaya Pesisir dan Kelautan (PUSPIS) IPB, Bogor.

Fuad. 2006. Analisis efesiensi operasi penangkapan kapal purse seine di perairan Probolingo. Tesis. Program Pasca Sarjana Program Studi Teknik Sistem dan Pengendalian Kelautan, Fakultas Teknologi Kelautan, Institul Teknologi 10 November, Surabaya.

Sastrodiwongso, T. 1985. Pengukuran tingkat kebisingan di atas kapal. Transtel Indonesia.

Suma'mur, P. K. 1996. Higiene Perusahaan dan Kesehatan Kerja. PT Gunung Agung, Jakarta.

Tambunan. 2005. Kebisingan di Tempat Kerja. CV Andi, Yogyakarta.

Undang-Undang Republik Indonesia No 21 Tahun 1992 tentang Pelayaran. 